\title{
An Examination of the Catalyst Layer Contribution to the Disparity between the Nernst Potential and Open Circuit Potential in Proton Exchange Membrane Fuel Cells
}

\author{
Peter Mardle $^{1}\left(\mathbb{D}\right.$, Isotta Cerri ${ }^{2}$, Toshiyuki Suzuki ${ }^{3}$ and Ahmad El-kharouf ${ }^{1, *(D)}$ \\ 1 School of Chemical Engineering, University of Birmingham, Edgbaston, Birmingham B15 2TT, UK; \\ peter_mardle@sfu.ca \\ 2 Toyota Motor Europe, Hoge Wei 33, 1930 Zaventem, Belgium; Isotta.Cerri@toyota-europe.com \\ 3 Toyota Motor Corporation, Toyota City 471-8571, Japan; toshiyuki_suzuki_ab@mail.toyota.co.jp \\ * Correspondence: a.el-kharouf@bham.ac.uk; Tel.: +44-121-414-5081
}

check for

updates

Citation: Mardle, P.; Cerri, I.; Suzuki, T.; El-kharouf, A. An Examination of the Catalyst Layer Contribution to the Disparity between the Nernst Potential and Open Circuit Potential in Proton Exchange Membrane Fuel Cells. Catalysts 2021, 11, 965 . https:// doi.org/10.3390/catal11080965

Academic Editors: Davide Clematis, Fabrice Mauvy and Jan Van Herle

Received: 14 July 2021

Accepted: 9 August 2021

Published: 12 August 2021

Publisher's Note: MDPI stays neutral with regard to jurisdictional claims in published maps and institutional affiliations.

Copyright: (c) 2021 by the authors. Licensee MDPI, Basel, Switzerland. This article is an open access article distributed under the terms and conditions of the Creative Commons Attribution (CC BY) license (https:// creativecommons.org/licenses/by/ $4.0 /)$.

\begin{abstract}
The dependency of the Nernst potential in an operating proton exchange membrane fuel cell (PEMFC) on the temperature, inlet pressure and relative humidity $(\mathrm{RH})$ is examined, highlighting the synergistic dependence of measured open circuit potential (OCP) on all three parameters. An alternative model of the Nernst equation is derived to more appropriately represent the PEMFC system where reactant concentration is instead considered as the activity. Ex situ gas diffusion electrode (GDE) measurements are used to examine the dependency of temperature, electrolyte concentration, catalyst surface area and composition on the measured OCP in the absence of $\mathrm{H}_{2}$ crossover. This is supported by single-cell OCP measurements, wherein RH was also investigated. This contribution provides clarity on the parameters that affect the practically measured OCP as well as highlighting further studies into the effects of catalyst particle surrounding environment on OCP as a promising way of improving PEMFC performance in the low current density regime.
\end{abstract}

Keywords: Nernst potential; open circuit potential; catalyst layer; OCP; OCV; PEMFC

\section{Introduction}

Proton exchange membrane fuel cells (PEMFCs) have a promising future in the energy sector due to their ability to generate energy from $\mathrm{H}_{2}$ gas at low temperatures, with no harmful pollutants. However, the quantity and high cost of the precious metal Pt catalyst required in order to achieve the needed power outputs from a stack have delayed the progress of PEMFC commercialisation [1,2]. A proposed stretch target of platinum group metal (PGM) content of around $0.0625 \mathrm{~g} \mathrm{~kW}^{-1}$ for a $90 \mathrm{~kW}$ stack needs to be met and thus the polarisation performance of membrane electrode assemblies (MEAs) with ultra-low catalyst loadings must be greatly improved [3].

Figure 1 shows a typical polarisation performance curve that progressively demonstrate activation, ohmic and mass transport losses against the cell current output, and the resultant decrease in PEMFC efficiency. Mass transport losses can be reduced by considering the material design and structure of the gas diffusion layer (GDL) [4,5], catalyst layer (CL) and patterning of the flow-field plates [6]. In particular, there is an ongoing focus on reducing the local $\mathrm{O}_{2}$ mass transport resistance in the ionomer thin film surrounding catalyst particles which, inhibits the adoption of ultra-low catalyst loadings [7]. Internal resistances are a function of the electrical conductivity of the flow-field plates, electrodes, the contact resistance between them and the proton conductivity of the membrane [8]. In particular, thinner membranes result in increased proton conductivity through a shorter mean free path. However, $\mathrm{H}_{2}$ crossover also becomes more prominent causing parasitic currents at the cathode [9-11]. Finally, activation losses have received the greatest attention in recent decades due to the large performance losses at the cathode, which translate across 
the entire polarisation performance curve. For simplicity, only the overpotential associated with the oxygen reduction reaction ( $\eta_{\mathrm{ORR}}$ ) is considered in the majority of the reported work. Due to the large activation overpotential, great efforts have been made into the development of more active Pt catalysts and $\mathrm{Pt}$ free catalysts towards the oxygen reduction reaction (ORR) [12]. However, despite the significant advancements and greater than 50 -fold activity enhancements over commercial $\mathrm{Pt} / \mathrm{C}$ catalysts at $0.9 \mathrm{~V}$ vs. $\mathrm{RHE}$, there is difficulty in translating ORR activity into reduced activation polarisation in an MEA environment $[2,13]$.

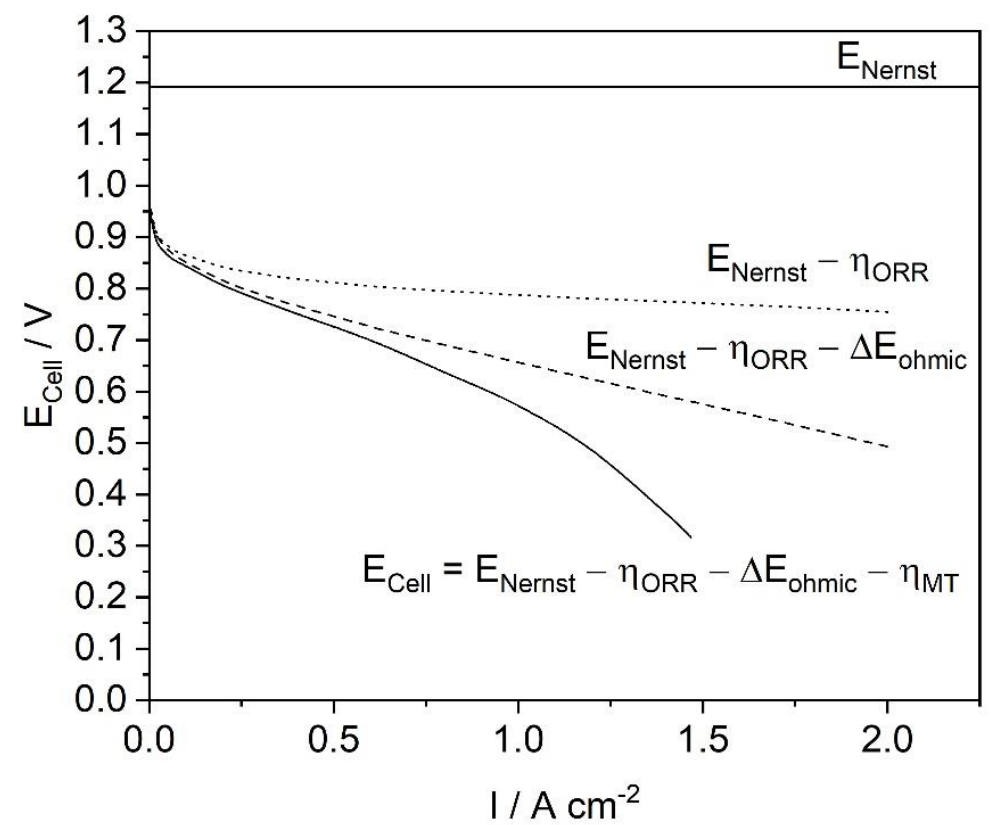

Figure 1. Example polarisation curves demonstrating the major losses which contribute to the deviation of the measured cell potential in comparison to the theoretical maximum Nernst equation.

While these efficiency losses affect the overall polarisation performance, when net zero current is being drawn from a PEMFC at open-circuit potential (OCP), the voltage measured should be equal to that defined by the Nernst equation (Equation (1)):

$$
\mathrm{E}_{\text {Nernst }}=\mathrm{E}_{298.15 \mathrm{~K}}^{0}-0.000846(\mathrm{~T}-298.15)+\frac{\mathrm{RT}}{\mathrm{nF}} \ln (\mathrm{Q})
$$

However, practically, this is not the case. One possible contribution is the small electronic conductivity of the membrane known as short circuit current [14]. A second contribution is that of a mixed potential where differential $\mathrm{Pt}$ species such as oxides at the catalyst surface with lower standard potentials result in a decrease of combined cathodic OCP. Zhang et al. suggested that at steady state, the Pt surface can have a coverage of $30 \% \mathrm{PtO}$ which with a standard potential of $0.88 \mathrm{~V}$ vs. normal hydrogen electrode (NHE), can reduce the overall cathode potential to around $1.06 \mathrm{~V}$ vs. NHE at $25^{\circ} \mathrm{C}$ and $1 \mathrm{~atm}$ $\mathrm{O}_{2}$ pressure [15]. A further decrease in OCP from the theoretically calculated values was attributed to $\mathrm{H}_{2}$ crossover, whereby $\mathrm{H}_{2}$ that diffuses through the membrane oxidises at the cathode, inducing equal current from the ORR to compensate. The work also demonstrated how a thinner Nafion ${ }^{\circledR} 112$ membrane suffers from greater $\mathrm{H}_{2}$ crossover currents and thus had measurably lower OCPs in comparison to Nafion ${ }^{\circledR} 117$. In addition to $\mathrm{H}_{2}$ crossover, any oxidising species such as organic impurities can contribute to a drop in OCP by a similar mechanism [16,17].

Mixed potential, hydrogen crossover and organic contamination can therefore be collated into a broad category of oxidative currents at the cathode, labelled in this report as $i_{\text {ox }}$. These oxidative currents cause a local response of compensating ORR which has a corresponding over-potential according to Tafel kinetics (Equation (2)): 


$$
\eta_{\text {ORR }}=b \cdot \log \left(\frac{i+i_{\text {Ox }}}{i_{0}}\right)
$$

Therefore, it can be seen that even with net zero current across the fuel cell, i.e., at OCP, the logathrimic function does not collapse as a result of the crossover currents and so there is an induced activation overpotential [18].

This contribution firstly analyses the theoretically achievable PEMFC potential at OCP as defined by the Nernst equation with an illustration of the dependences on temperature, inlet gas pressure and relative humidity (RH). Ex situ gas diffusion electrode (GDE) characterisation is then used to examine the temperature dependency of OCP in an environment exempt from $\mathrm{H}_{2}$ crossover. An alternative aqueous model of the Nernst potential is then presented to provide a description of the thermodynamic maximum potential that better conceptualises the real processes occurring. Further GDE experimentation in conjunction with $\mathrm{O}_{2}$ solubility measurements are then used to examine the dependency of OCP on electrolyte concentration whereby electrolyte choice and dissolved $\mathrm{O}_{2}$ concentration are shown to be contributing factors. The effects of catalyst surface area and composition are then examined ex situ to critically demonstrate their contribution to OCP. The effects of surface area are then presented in MEA single cell experiments where the change of the dependency due to the inclusion of $\mathrm{H}_{2}$ crossover is shown and discussed in the context of the drive towards ultra-low PGM content MEAs. The effect of RH on OCP is finally examined in the single cell whereby deviations from the theoretical dependency highlights the need to consider not just catalyst materials but also the entire catalyst/ionomer system at low current densities.

\section{Results and Discussion}

\subsection{Dependence of the Nernst Potential on Temperature, Pressure, and $R H$}

The overall reaction in a PEMFC system is shown in Equation (3) with the quoted standard Gibbs free energy change, $\Delta \mathrm{G}_{\mathrm{f}}{ }^{0}$ at $25^{\circ} \mathrm{C}$ operating temperature:

$$
\mathrm{H}_{2(\mathrm{~g})}+\frac{1}{2} \mathrm{O}_{2(\mathrm{~g})} \rightarrow \mathrm{H}_{2} \mathrm{O}_{(\mathrm{l})} \Delta \mathrm{G}_{\mathrm{f}}^{0}=-237.2 \mathrm{~kJ} \mathrm{~mol}^{-1}
$$

Using Equation (4) this energy change translates into a theoretical maximum cell potential of around $1.23 \mathrm{~V}$.

$$
\mathrm{E}_{\mathrm{Cell}}^{0}=\frac{-\Delta \mathrm{G}_{\mathrm{f}}^{0}}{\mathrm{nF}}
$$

The Nernst equation provides a correction whereby the empirically derived temperature dependency of the standard cell potential (see supplementary information Section 1) is followed by an additional function of the reactants and products electrochemical activities. The activity of a species can be defined as the effective concentration and thus partial pressure can be used as a descriptor for ideal gases. Considering the activity of water as 1 , the conventionally used Nernst equation follows as:

$$
\mathrm{E}_{\text {Nernst }}=\mathrm{E}_{298.15 \mathrm{~K}}^{0}-0.000846(\mathrm{~T}-298.15)+\frac{\mathrm{RT}}{4 \mathrm{~F}} \ln \left(\mathrm{pH}_{2(\mathrm{~g})}{ }^{2} \cdot \mathrm{pO}_{2(\mathrm{~g})}\right)
$$

To explore this equation, the effect of $\mathrm{RH}$ on partial pressure the thermodynamic maximum cell potential was accounted for (inlet pressure $=p_{g}+p_{v a p}$ ) and thus $E_{\text {Nernst }}$ was calculated for a range of temperatures, inlet pressures and $\mathrm{RH}$ values (Figure 2a). The inlet pressure was assumed to be equal at both the cathode and anode with pure $\mathrm{O}_{2}$ in the cathode gas stream. From this figure, the importance of these parameters and their synergistic effect on the Nernst potential can be observed. For example, at higher temperatures and lower pressures, the dependency of $\mathrm{E}_{\text {Nernst }}$ on $\mathrm{RH}$ increases as $\mathrm{p}_{\mathrm{vap}}$ constitutes a greater proportion of the inlet gas pressure (Figure $2 b$ ). Therefore, for $a$ PEMFC running at $80^{\circ} \mathrm{C}$, while high $\mathrm{RH}$ values may be required to ensure adequate proton transport through the membrane, the OCP of the cell is decreased. The understanding of 
these synergistic effects is important for the design of the appropriate conditions when operating a PEMFC for a given application.
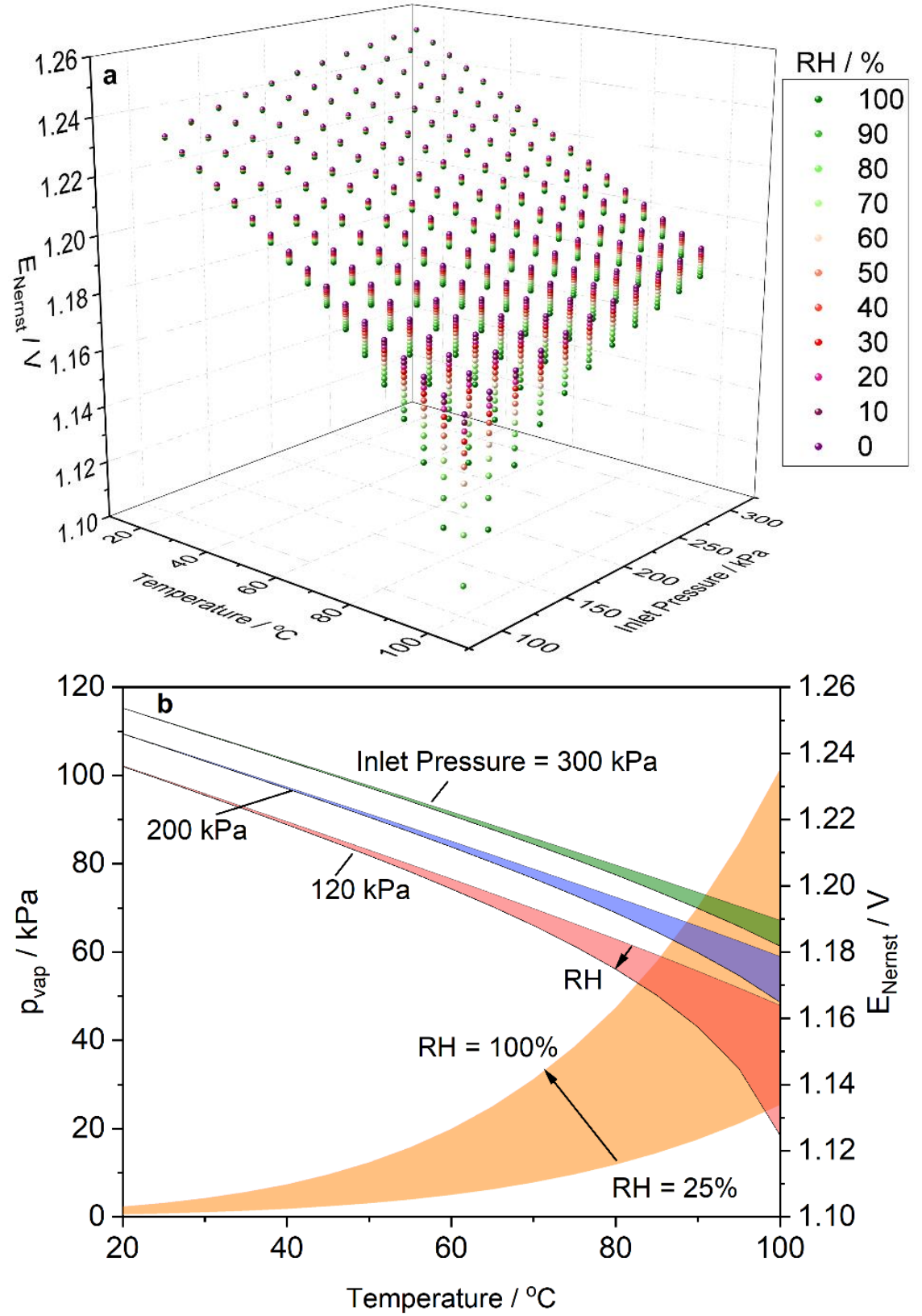

Figure 2. (a) The Nernst potential, $\mathrm{E}_{\text {Nernst }}$ calculated in the temperature range $20-100{ }^{\circ} \mathrm{C}$, inlet pressure range $101.3-300 \mathrm{kPa}$ and $\mathrm{RH}$ range $0-100 \%$. Product $\mathrm{H}_{2} \mathrm{O}$ in the liquid form only is assumed. (b) The effect of RH on $p_{v a p}$ and the corresponding effect on $E_{\text {Nernst }}$.

\subsection{Nernst Equation and Temperature Dependency}

The temperature dependency of $\mathrm{E}_{\mathrm{Nernst}}$ and thus the measured OCP was examined ex situ to highlight the disparity in OCP to $\mathrm{E}_{\text {Nernst }}$ in the absence of $\mathrm{H}_{2}$ crossover. A commercial GDE was heated to $67^{\circ} \mathrm{C}$ and the OCP was initially measured. The cell was then left to naturally cool while the $\mathrm{OCP}$ was recorded at each $1^{\circ} \mathrm{C}$ drop in cell temperature until a final measurement was taken at $30.6^{\circ} \mathrm{C}$. Figure 3 shows the experimental results with a linear trend similar to that calculated using the partial pressures of $1 \mathrm{~atm}$ for $\mathrm{O}_{2}$ and $\mathrm{H}_{2}$ gases. This can be illustrated by the gradient of the OCP drop, which was found to be $-0.992 \mathrm{mV}^{\circ} \mathrm{C}^{-1}$ for the experimental results, compared to $-0.846 \mathrm{mV}{ }^{\circ} \mathrm{C}^{-1}$ for the theoretical calculation. The significant difference of $>150 \mathrm{mV}$ can be explained as the result 
of a mixed potential of Pt oxides and organic contaminants, acknowledging the absence of $\mathrm{H}_{2}$ crossover in the ex situ measurements. For example, Reimer et al. recently examined the time dependence of the measured OCP on a Pt disk electrode where similar OCPs and temperature dependency was shown once steady state was reached [19].

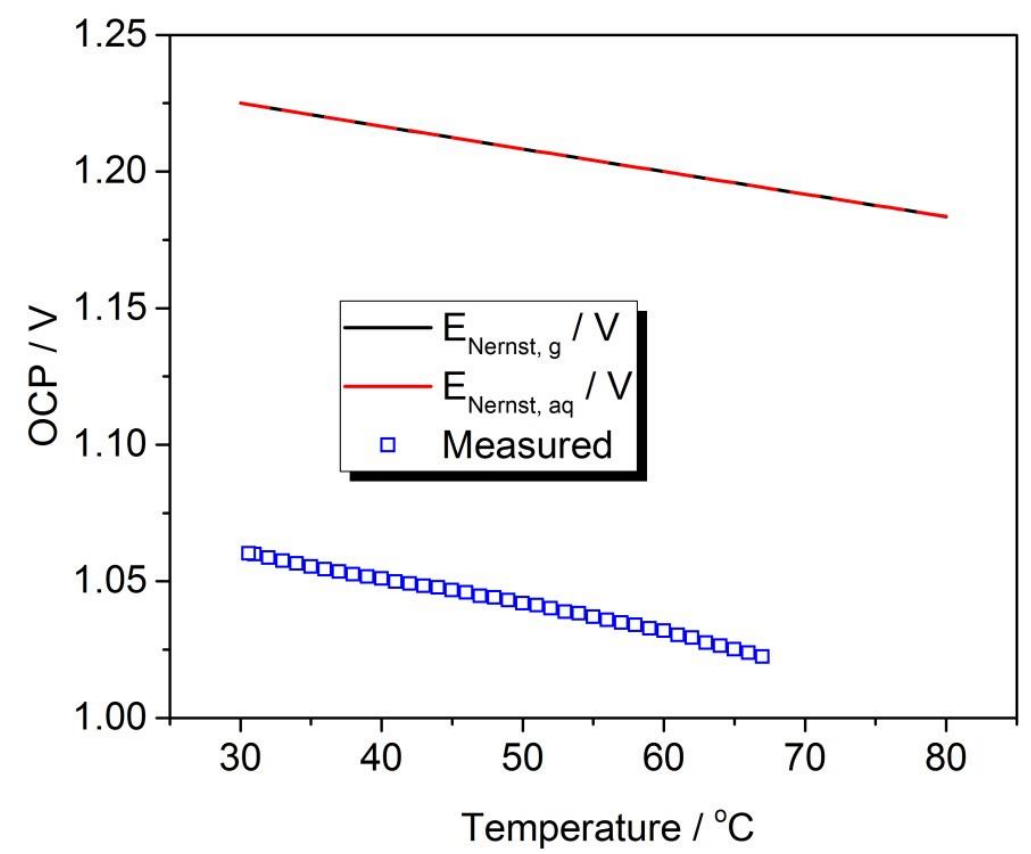

Figure 3. Calculated OCP dependence on temperature based on the Nernst equation using both the gaseous (Equation (5)) and aqueous (Equation (16)) models in addition to the experimentally measured OCPs for a Pt/C (JM) GDE.

Interestingly, they suggested much reduced theoretical Nernst potentials and better agreement with experimental values when the reactant concentration was taken as the reactant activity in place of partial pressure. This is because the local environment around the catalyst surface is that of dissolved $\mathrm{O}_{2}$ and $\mathrm{H}_{2}$ within a surrounding ionomer layer, rather than a traditionally described triple phase boundary. However, at equilibrium the Nernst potential calculated in either case; reactant concentration or partial pressure should be equal. We have also considered this approach and here present the derivation of the Nernst potential as a model of the aqueous system (e.g., dissolved $\mathrm{O}_{2}$ and $\mathrm{H}_{2}$ as opposed to gaseous reactants), whereby the temperature dependency was re-examined and the reason for the reduced theoretical Nernst potentials when using the reactant concentration as shown in [20] is explained.

Initially, it must be considered that the chemical potential of $\mathrm{O}_{2}$ and $\mathrm{H}_{2}$ in both the gaseous and aqueous phases at equilibrium are necessarily equal (Equation (6)):

$$
\mu_{\mathrm{g}}=\mu_{\mathrm{aq}}
$$

Equation (7) relates the chemical potential to that of the standard chemical potential and the reactant activity:

$$
\mu=\mu^{0}+R \ln (a)
$$

Combining Equations (6) and (7), as well as considering the appropriate representation of activity in each phase, it follows that:

$$
\mu_{\mathrm{g}}^{0}+R \operatorname{Tln}\left(\mathrm{p}_{\mathrm{g}}\right)=\mu_{\mathrm{aq}}^{0}+R \operatorname{Rln}\left(\mathrm{C}_{\mathrm{aq}}\right)
$$

The inequivalent activities result in unequal standard free energies in each state. The difference in free energy can be related to the change of free energy of dissolution by Equation (9): 


$$
\mu_{\mathrm{aq}}^{0}=\mu_{\mathrm{g}}^{0}+\Delta \mathrm{G}_{\mathrm{diss}}^{0}
$$

Combining Equations (8) and (9), as well as considering Henrys law (Equation (10)), the free energy change of dissolution can be calculated from Henry's law constant by Equation (11):

$$
\begin{gathered}
\mathrm{C}_{\mathrm{aq}}=\mathrm{H} \mathrm{p}_{\mathrm{g}} \\
\Delta \mathrm{G}_{\text {diss }}^{0}=\mathrm{RT} \ln \left(\frac{1}{\mathrm{H}}\right)
\end{gathered}
$$

For the gaseous model, the overall change in Gibbs free energy is calculated from the change of chemical energy of the gaseous system:

$$
\Delta \mathrm{G}_{\mathrm{f}, \mathrm{g}}^{0}=\mu_{\mathrm{H}_{2} \mathrm{O}_{(\mathrm{l})}}^{0}-\mu_{\mathrm{H}_{2(\mathrm{~g})}}^{0}-\frac{\mu_{\mathrm{O}_{2(\mathrm{~g})}}^{0}}{2}
$$

If reactant activity is considered to be due to dissolved gas concentration, then the Gibbs free energy change of the aqueous system must be considered where:

$$
\begin{gathered}
\left.\Delta \mathrm{G}_{\mathrm{f}, \mathrm{aq}}^{0}=\mu_{\mathrm{H}_{2} \mathrm{O}_{(\mathrm{l})}}^{0}-\mu_{\mathrm{H}_{2(\mathrm{aq})}}^{0}-\frac{\mu_{\mathrm{O}_{2(\mathrm{aq})}}^{0}}{2}\right) \\
\Delta \mathrm{G}_{\mathrm{f}, \mathrm{aq}}^{0}=\mu_{\mathrm{H}_{2} \mathrm{O}_{(\mathrm{l})}}^{0}-\left(\mu_{\mathrm{H}_{2(\mathrm{~g})}}^{0}+\Delta \mathrm{G}_{\text {diss, } \mathrm{H}_{2}}^{0}\right)-\left(\frac{\mu_{\mathrm{O}_{2(\mathrm{~g})}}^{0}+\Delta \mathrm{G}_{\text {diss, } \mathrm{O}_{2}}^{0}}{2}\right) \\
\Delta \mathrm{G}_{\mathrm{f}, \mathrm{aq}}^{0}=\Delta \mathrm{G}_{\mathrm{f}, \mathrm{g}}^{0}-\Delta \mathrm{G}_{\text {diss }, \mathrm{H}_{2}}^{0}-\frac{\Delta \mathrm{G}_{\text {diss, } \mathrm{O}_{2}}^{0}}{2}
\end{gathered}
$$

Therefore, making the distinction of a different $\mathrm{E}^{0}$ in the aqueous model, the Nernst equation for the aqueous system becomes:

$$
\mathrm{E}_{\mathrm{Nernst}}=\mathrm{E}_{\mathrm{aq}}^{0}+\frac{\mathrm{RT}}{4 \mathrm{~F}} \ln \left(\left[\mathrm{H}_{2(\mathrm{aq})}\right]^{2} \cdot\left[\mathrm{O}_{2(\mathrm{aq})}\right]\right)
$$

This form of the Nernst equation was explored within the temperature range of 30-80 ${ }^{\circ} \mathrm{C}$ and compared to the gaseous system where the standard Gibbs free energy for water formation was calculated from the changes in standard enthalpy and entropies, rather than the approximation of Equation (5). For the aqueous system, the Van't Hoff equation was used to calculate the theoretical Henry's law constant for $\mathrm{O}_{2}$ and $\mathrm{H}_{2}$ in this temperature range, where the pressure of both gases was taken to be $1 \mathrm{~atm}$ and the electrolyte was assumed to be liquid $\mathrm{H}_{2} \mathrm{O}$ due to accessibility of numerical data [20]. These constants were then used to approximate both $\mathrm{C}_{\mathrm{aq}}$ of $\mathrm{H}_{2}$ and $\mathrm{O}_{2}$ as well as $\Delta \mathrm{G}^{0}$ diss (see Supplementary Information Section 2). Equation (16) was finally used to calculate the Nernst potential which as plotted in Figure 3 shows identical values to that obtained using the gaseous model, as expected considering that at steady state the chemical potential of the reactants must be equal. However, while conventional gaseous models accurately predict the Nernst potential, the aqueous model provides a more accurate description of the thermodynamic potential of an operational catalyst layer, providing a useful perspective for when the system is not considered to be at steady state as in this work.

\subsection{Electrolyte Concentration}

Using the ex situ GDE setup, the effect of electrolyte concentration on OCP was measured using both $\mathrm{HClO}_{4(\mathrm{aq})}$ and $\mathrm{H}_{2} \mathrm{SO}_{4(\mathrm{aq})}$. These are common electrolytes for the ex situ characterization of catalysts where $\mathrm{H}_{2} \mathrm{SO}_{4(\mathrm{aq})}$ more closely resembles sulfonic acid functionalized ionomers but $\mathrm{HClO}_{4(\mathrm{aq})}$ avoids negative effects such as (bi)sulfate adsorption, a known inhibitor of ORR kinetics [21]. It was found that by increasing the concentration of the acid solution, measured OCP decreased (Figure 4a). Additionally, lower OCPs were observed for $\mathrm{H}_{2} \mathrm{SO}_{4(\mathrm{aq})}$ in comparison to $\mathrm{HClO}_{4(\mathrm{aq})}$ when used as the 
electrolyte, likely because of the aforementioned (bi)sulfate adsorption, highlighting kinetic limitations at OCP even though no net current is drawn.
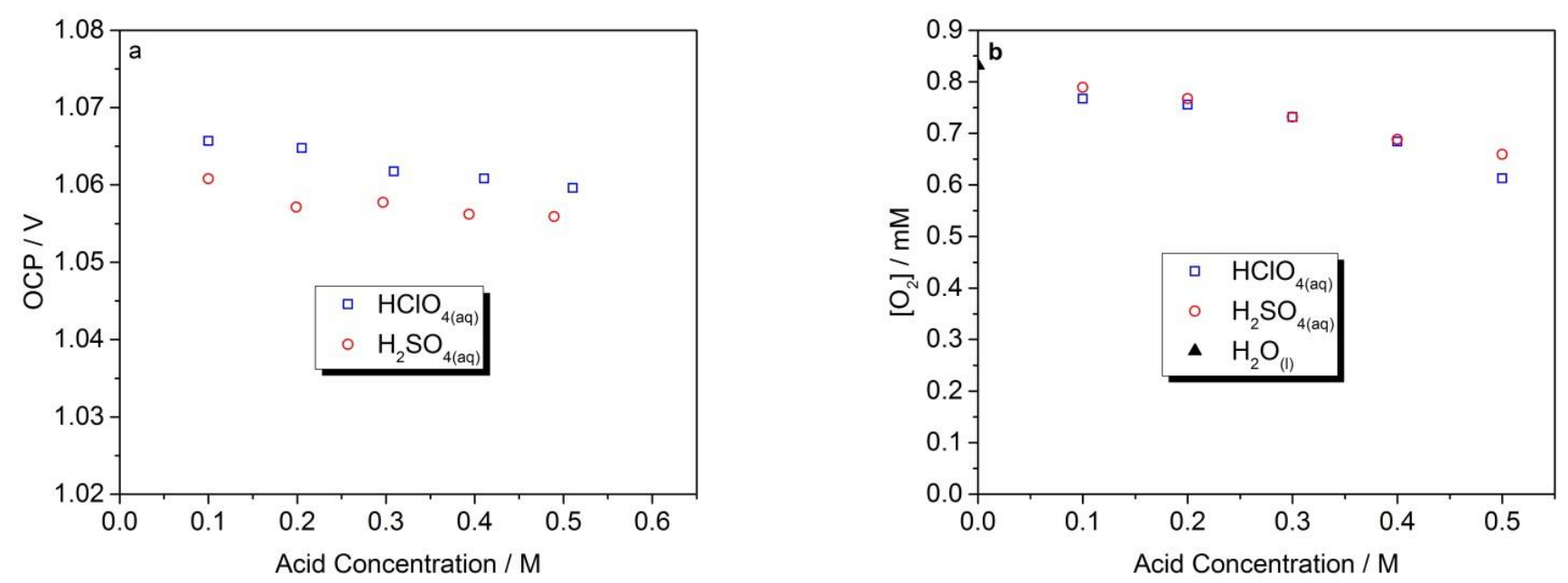

Figure 4. (a) The measured OCP of a Pt/C (JM) GDE with different acid concentrations. (b) The measured $\left[\mathrm{O}_{2}\right]$ in the electrolytes through use of a Clark cell.

To elucidate the OCP dependence on electrolyte concentration, $\left[\mathrm{O}_{2}\right]$ in the saturated electrolytes was measured using a Clark cell (WPI ISO2). Previous calculations gave a baseline saturated $\mathrm{O}_{2}$ concentration of $0.831 \mathrm{mM}$ in $\mathrm{H}_{2} \mathrm{O}$ and this was used as the baseline for the measurement. Figure $4 \mathrm{~b}$ shows a linear drop in $\left[\mathrm{O}_{2}\right]$ for an increase in acid concentration (rate $=-0.364 \mathrm{mM} \mathrm{M}_{\mathrm{acid}^{-1}}{ }^{-1}$ ), clearly indicating that despite the Nernst potential being invariant to reactant concentration-where an increase in saturation concentration leads to a drop in Henry's constant and thus a respective increase in $\Delta \mathrm{G}^{0}$ diss - measured OCP is not, with implications discussed in Section 2.5.

\subsection{Ex Situ GDEs-The Effect of Pt Surface Area and Catalyst Composition on OCP}

As shown by Equation (2), at OCP, there is an ORR equal and opposite to the oxidative currents from the mixed potential and oxidation of various contaminants. One of the biggest breakthroughs for PEMFC development is the fabrication of $\mathrm{Pt} / \mathrm{C}$ catalysts with Pt particle diameters of just 3-5 nm, providing superior catalyst utilisation in comparison to previous Pt black catalysts. Gasteiger et al. had previously conducted a detailed investigation into the effects of catalyst loading on PEMFC performance [22]; however, special attention is drawn here onto the effect on OCP. Using a commercially available $\mathrm{Pt} / \mathrm{C}$ catalyst (FC Store), electrodes of variable Pt loading (and thus catalyst surface area) were fabricated and the OCP measured using the ex situ GDE apparatus (Figure 5). Clearly, the OCP is dependent on the catalyst surface area and from the experimental data collected, it appears to follow a logarithmic relationship as would be suggested by Equation (2).

This experiment was repeated with commercial $\mathrm{Pt}_{3} \mathrm{Co} / \mathrm{C}$ and $\mathrm{Pt}_{3} \mathrm{Ni} / \mathrm{C}$ catalysts with both showing similar relationships but with positive shifts in OCP. To ascertain whether this positive shift was due to increased ORR kinetic activity, a Tafel analysis was adopted where, in short, EIS was used to correct for internal resistances while the current was corrected for by shifting all values so that the current at the independently measured OCP equals 0 A. A Tafel plot was then made and the Tafel region was extrapolated to the theoretical OCP at $30^{\circ} \mathrm{C}$ of $1.225 \mathrm{~V}$ vs. RHE, where the exchange current density for the ORR is obtained. Using Equation (2), the oxidative current contributing to the mixed potential was then calculated. This also corresponds to the current of the Tafel plot at the measured OCP. 

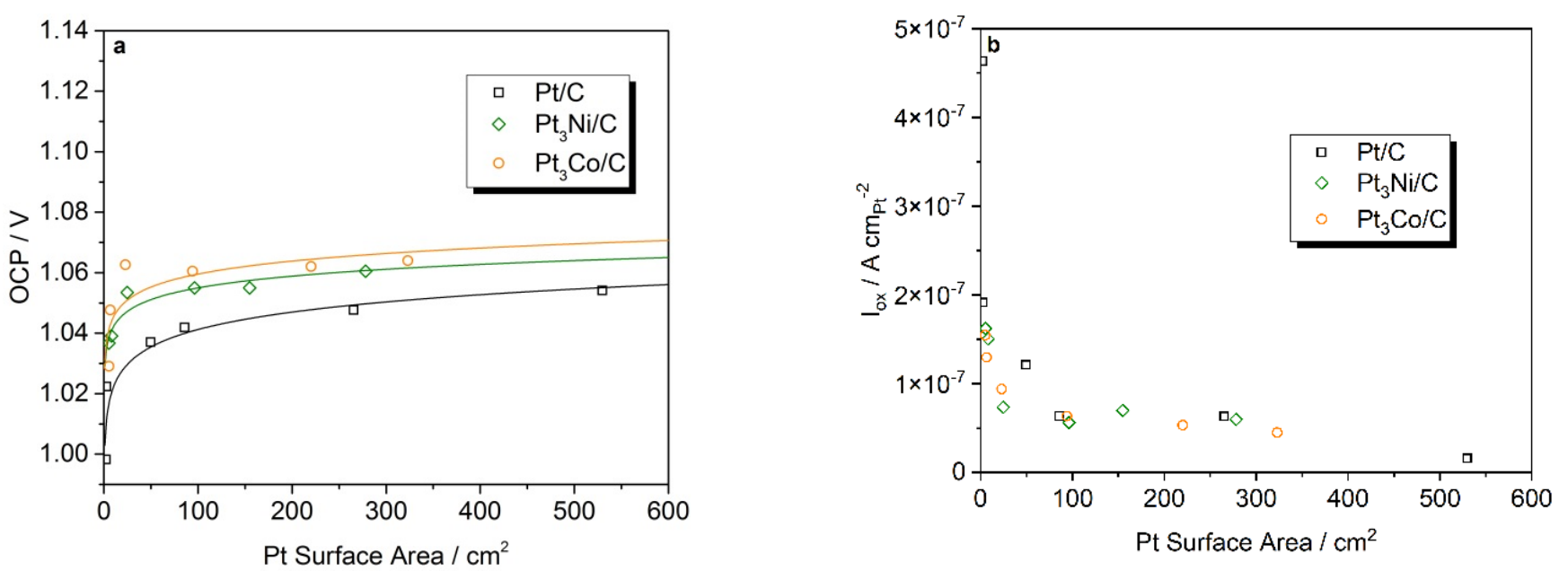

Figure 5. (a) The dependency of OCP on $\mathrm{Pt}$ surface area measured on $\mathrm{Pt} / \mathrm{C}, \mathrm{Pt}_{3} \mathrm{Ni} / \mathrm{C}$ and $\mathrm{Pt}_{3} \mathrm{Co} / \mathrm{C}$ GDEs of various loadings ex situ in $0.1 \mathrm{M} \mathrm{HClO}_{4(\mathrm{aq})}$ electrolyte at $30^{\circ} \mathrm{C}$. (b) Calculated oxidative current normalised to Pt surface area vs. Pt surface area.

It was found that the Tafel slope was independent of the catalyst surface area (Figure S4), which is understandable as the slope is dependent on the rate determining step for the ORR [23]. However, this should not change with the catalyst surface area but could change with the composition of the catalyst by virtue of alternative reaction pathways. In this case though, it does not and the average Tafel slope for all samples is $57 \mathrm{mV} \mathrm{dec}^{-1}$ in the kinetically limited region, indicating that all tested catalysts are dominated by the dissociative ORR pathway [24]. Due to the associated errors with such an extrapolation of the Tafel plot, there is some variance in the exchange current density obtained (Figure S5); however, it is clear that the alloy catalysts have better kinetic activity towards the ORR. This is unsurprising because alloying Pt with non-noble metals such as $\mathrm{Ni}$ and Co results in improved catalytic performance through electronic and structural effects such as surface lattice contraction on the $\mathrm{Pt}$ [25]. This corresponds with the shift in OCP to higher values for the samples in Figure 6a and with reference to Equation (2) is due to a smaller " $\mathrm{i}_{\mathrm{ox}} / \mathrm{i}_{0}$ " function at OCP. The higher OCPs for catalyst materials that are more active to the ORR provide further evidence that at OCP, oxidative currents on the GDE induce some ORR to compensate. The larger the exchange current of the catalyst, the smaller the overpotential induced.

To further examine the effect of Pt surface area, the current contributing to the mixed potential, $\mathrm{i}_{\mathrm{ox}}$ was calculated and plotted vs. Pt surface area in Figure $5 \mathrm{~b}$. While the value is independent of catalyst activity, it is highly dependent on the Pt surface area as an inverse function. These results therefore highlight the dependence of OCP on not just the total size of oxidative currents but the magnitude with respect to number of active $\mathrm{Pt}$ sites. The implications are such that unless suitable corrections for oxidative currents are made during ex situ evaluation of ORR catalytic activity, such as in thin-film rotating disk electrode experiments [21], the activity of thin films with smaller total catalyst surface area will be disadvantaged compared to thin films with higher catalyst surface area.

\subsection{MEA Testing}

GDEs of varying Pt loading on both sides of the electrode were fabricated and multiple tests were performed as described in Section 2.3. In the MEA, the Pt surface area, RH and $\mathrm{H}_{2}$ crossover current all contribute to the $\mathrm{OCP}$ and so deconvolution of each parameter is difficult. Crucially, in comparison to the ex situ measurements, $\mathrm{H}_{2}$ crossover can be measured directly by saturating the cathode with $\mathrm{N}_{2}$ and recording the steady state current at $0.5 \mathrm{~V}$, giving a measured approximation for the oxidative currents [26]. The measured crossover current was normalised to the Pt surface area on the cathode and compared to the Pt surface area (Figure 6a), much like the oxidative currents in Figure 5b. Analogously, 
the results illustrate that the oxidative currents experienced on the cathode catalysts in the MEA environment, normalised to surface area, are smaller with an increase in surface area on the electrode. Therefore, a greater initial over-potential can again be expected for those electrodes with a smaller surface area as confirmed in Figure $6 \mathrm{~b}$. This means that within the context of ultra-low Pt loadings in practical PEMFCs, for example the DoE stretch target loadings of $0.05 \mathrm{mg}_{\mathrm{Pt}} \mathrm{cm}^{-2}$ at the cathode, $\mathrm{H}_{2}$ crossover has a greater effect on the overpotential at OCP than the same levels of crossover would for higher Pt loadings. This highlights the synergistic effects of all PEMFC components and implies that for MEAs with low Pt loadings and thin membranes, the initial overpotential will be significantly large with key differences in the measurable shape of the polarisation curve in the low current density region.
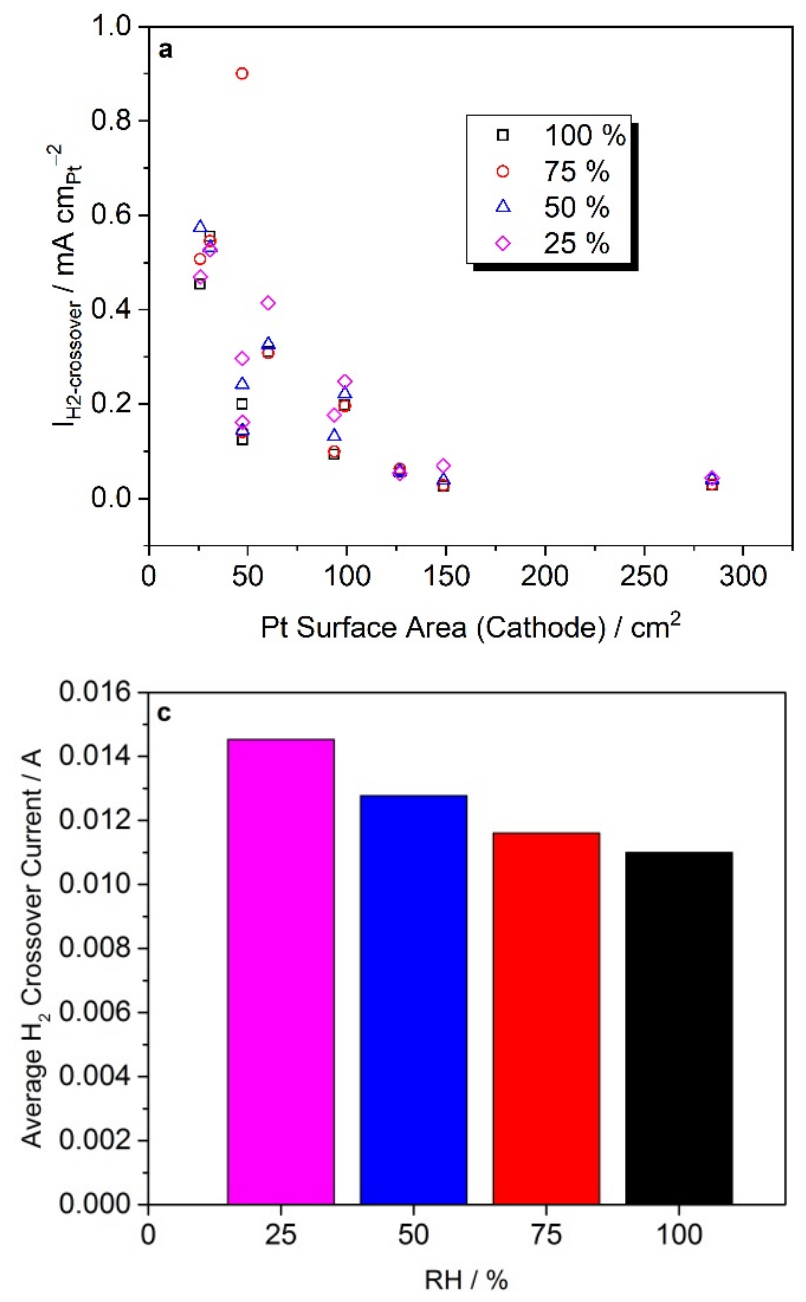
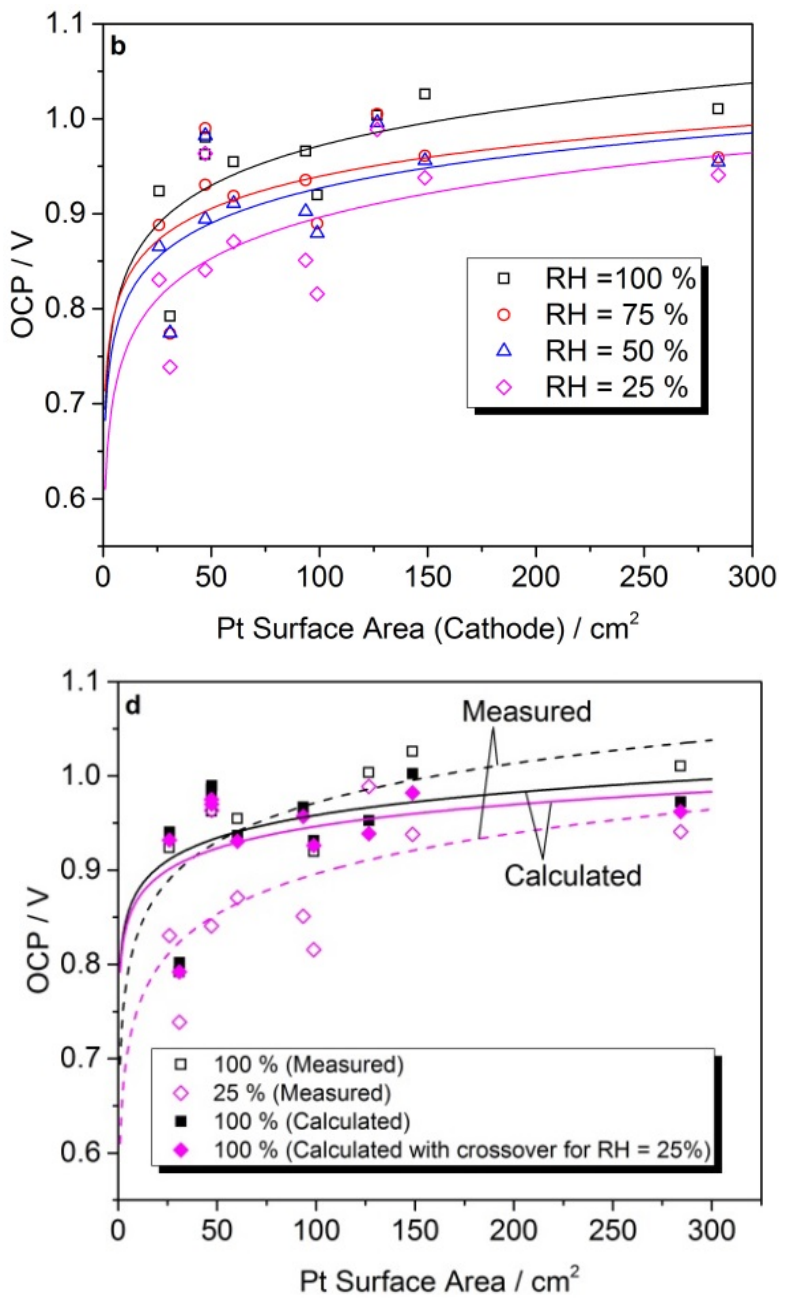

Figure 6. (a) $\mathrm{H}_{2}$ crossover current normalised by Pt surface area vs. Pt surface area for all $4 \mathrm{RH}$ values tested, (b) OCP vs. Pt surface area at the cathode for all $\mathrm{RH}$ values, (c) average $\mathrm{H}_{2}$ crossover current vs. $\mathrm{RH}$ and (d) the measured and calculated dependency of OCP on Pt surface area for RH values of $100 \%$ and $25 \%$. The calculated value for $25 \%$ is based off the $100 \%$ data with the added crossover current of $3.53 \mathrm{~mA}$ as per (c).

The OCP for each MEA was also recorded at multiple RH values and in direct contrast of Figure 2, a decrease in OCP was found to coincide with a decrease in RH. This can be partially attributed to the increase in $\mathrm{H}_{2}$ crossover at lower $\mathrm{RH}$ values (Figure 6c). Even though the partial pressure of $\mathrm{H}_{2}$ at the anode is higher at lower $\mathrm{RH}$ values, studies have concluded that it is neither the pressure nor the pressure differential that influences the level of $\mathrm{H}_{2}$ crossover [27]. Rather, crossover occurs primarily by a diffusion mechanism. The same work by Schalenbach et al., however, also shows that $\mathrm{H}_{2}$ permeability increases with relative humidity by virtue of a widening of the channels within the Nafion membrane. 
The opposite trend observed in this work is thought to be from a switching of crossover mechanism where permeation by differential pressure is favoured at lower relative humidity [28]. Figure S7 shows the absolute $\mathrm{H}_{2}$ crossover current vs. the $\mathrm{Pt}$ surface area at the anode and from this the rate of crossover appears to be independent of the amount of catalyst, indicating that the primary factor in this experiment is the hydration state of the polymer electrolyte as a function of the humidity of the gas feed.

Considering just the dependence of $\mathrm{H}_{2}$ crossover on $\mathrm{RH}$ was found to be insufficient to fully account for the entirety of the OCP drop. The difference in average crossover current between the MEAs at RH $100 \%$ and RH $25 \%$ was $3.53 \mathrm{~mA}$ and so if this was compensated for in the data for RH $100 \%$, then similar OCPs should be expected. The OCP for the RH 100\% data using Equation (2) was calculated using Tafel slopes and exchange currents obtained from a Tafel analysis on the MEAs analogous to the ex situ GDEs (see Supplementary Information Section 5). A comparison of the measured and calculated OCPs in Figure $6 \mathrm{~d}$ shows some differences; however, this is thought to be a result of extrapolations required in the Tafel analysis. This data was then adjusted by adding $3.53 \mathrm{~mA}$ onto the crossover measured as well as accounting for the increased partial pressure of $\mathrm{O}_{2}$ and $\mathrm{H}_{2}$ at $\mathrm{RH} 25 \%$ resulting in a higher $\mathrm{E}_{\mathrm{Nernst}}$. The OCP was then re-calculated and showed only a slight decrease in OCP compared to the theoretical values at RH 100\%. While the difference between measured OCPs at $100 \%$ and $25 \% \mathrm{RH}$ were found to be approximately $84 \mathrm{mV}$, the calculated values indicate that the increase in $\mathrm{H}_{2}$ crossover only accounts for $6 \mathrm{mV}$ of this.

The larger difference in OCP in the cell operating at $25 \% \mathrm{RH}$ and $100 \% \mathrm{RH}$ might additionally be attributed to (i) changes in local reactant concentration, and (ii) the change in ORR kinetics at the catalyst surface (kinetic analysis of the MEAs was not possible at low RH values due to ill-defined Tafel regions). Using Faraday's law, the molar flux of $\mathrm{O}_{2}$ used to compensate the $\mathrm{H}_{2}$ crossover current of $11 \mathrm{~mA}$ ( $\mathrm{RH} 100 \%$ in Figure 6c) can be calculated as around $3 \times 10^{8} \mathrm{~mol} \mathrm{~s}^{-1}$ and so considering reactant concentration as a descriptor of activity (Equation (16)) and the ultra-low concentrations measured in liquid electrolyte (Figure 5), measured OCP can be considered highly dependent on the rate of gas dissolution into the local catalyst environment to prevent Nernst potential drop.

In recent years, Morimoto et al. have shown high resistivity of $\mathrm{O}_{2}$ permeation through the ionomer layer, in particular at the catalyst/ionomer interface [29-32]. While the impact at high current densities is thought to be a major factor inhibiting further reductions in PGM content [3], these results show that even at $\mathrm{OCP}, \mathrm{O}_{2}$ permeability resistance is most likely a factor in the initial Nernst potential loss. As such, ionomers with higher $\mathrm{O}_{2}$ solubility and permeability can be expected to demonstrate higher OCPs. For example, Snyder et al. showed much enhanced ORR activity of nanoporous NiPt nanoparticles when impregnated with an ionic liquid with high $\mathrm{O}_{2}$ solubility and so there are clear indications that the local environment around the catalyst surface, i.e., ionomer composition has a direct impact on measured OCPs and PEMFC performance at low current densities [33].

\section{Materials and Experiments}

\subsection{Ex Situ GDE Measurements}

For all ex situ measurements, a half cell arrangement was made using a FlexCell (PTFE) (Gaskatel) as previously described [34]. The cell consists of a gas compartment in which a rectangular GDE $\left(5 \times 3 \mathrm{~cm}^{2}\right)$ was held by O-rings of $3 \mathrm{~cm}^{2}$ active area. A gas flow controller kept the gas flow into the back of the GDE at 0.4 SCFH $\left(189 \mathrm{~mL} \mathrm{~min}^{-1}\right)$ and the outlet was submerged in a beaker of DI water. A commercial HydroFlex reference hydrogen electrode (RHE) (Gaskatel) was used and linked to the surface of the working electrode by a luggin channel separated from the main electrolyte compartment as shown in Figure 7. Electrolyte solution was used to flush the channel and ensure no gas bubbles were present. A Pt coil counter electrode is built into the FlexCell. The electrolyte used was $0.1 \mathrm{M} \mathrm{HClO}_{4(\mathrm{aq})}$ (Fisher scientific, diluted in house) unless otherwise stated. The temperature of the cell was controlled via two heating plates that insert to the side of the PTFE cell and a temperature measurement feedback using a thermocouple inserted in the 
electrolyte solution. Three parameters were investigated using the ex situ setup, namely, operating temperature, electrolyte concentration and catalyst loading.

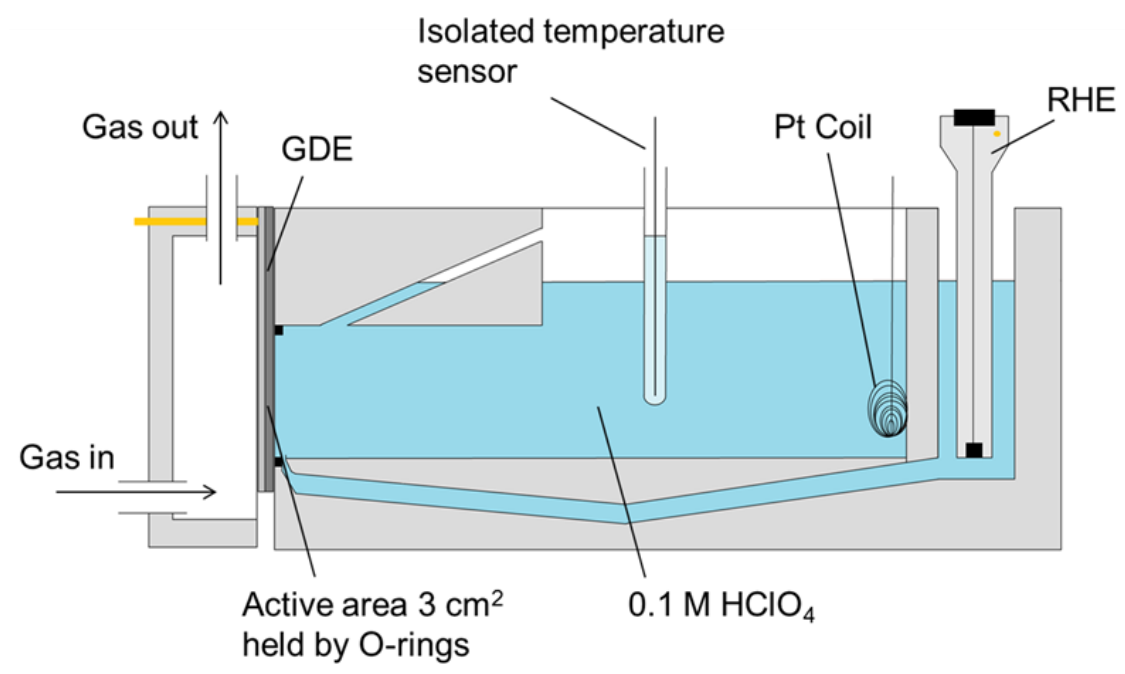

Figure 7. An illustration of the ex situ apparatus used in GDE testing. Reprinted with permission from ref [34]. Copyright 2020 American Chemical Society.

To study the effect of temperature on OCP, a commercial Johnson Matthey (JM) GDE $\left(0.4 \mathrm{mg}_{\mathrm{Pt}} \mathrm{cm}^{-2}\right)$ was used as the working electrode and the gas was initially set to $\mathrm{N}_{2(\mathrm{~g})}$. After $100 \mathrm{CV}$ cycles in the range $0.05-1.2 \mathrm{~V}$ vs. RHE at $100 \mathrm{mV} \mathrm{s}^{-1}, 2 \mathrm{CV}$ cycles in the same potential range at $20 \mathrm{mV} \mathrm{s}^{-1}$ scan rate were run at various temperatures $(31.7,40,53,60$ and $67^{\circ} \mathrm{C}$ ). The last cycle was taken for Pt surface area analysis using the $\mathrm{H}_{\text {des }}$ current [21]. At $67^{\circ} \mathrm{C}$, the gas was then switched to $\mathrm{O}_{2}$ and allowed to reach saturation. The OCP was then measured every $1{ }^{\circ} \mathrm{C}$ while the cell cooled down.

To measure the effect of electrolyte concentration on the OCP, a fresh JM GDE was used and the temperature was fixed at $30^{\circ} \mathrm{C}$. For this study, the experiments were conducted using $\mathrm{HClO}_{4(\mathrm{aq})}$ and $\mathrm{H}_{2} \mathrm{SO}_{4(\mathrm{aq})}$ (Sigma-Aldrich, Gillingham, UK), diluted in house), and the acid concentration was varied from $0.1 \mathrm{M}$ to $0.5 \mathrm{M}$. The standard break-in procedure of $100 \mathrm{CVs}$ in the range $0.05-1.2 \mathrm{~V}\left(100 \mathrm{mV} \mathrm{s}^{-1}\right)$ was run in $\mathrm{N}_{2}$ rich solution before performing the OCP measurements. The gas was changed to $\mathrm{O}_{2}$ and the OCP was monitored until a stable value was reached. At each step, sufficient amounts of the concentrated acid was added to increase the concentration by $0.1 \mathrm{M}$ and mixed into the electrolyte before another OCP reading was taken. This process was repeated to give a total of 5 data points.

For the catalyst loading study, GDEs with approximate Pt loadings of $0.0125,0.025$, $0.05,0.1,0.2$ and $0.4 \mathrm{mg}_{\mathrm{Pt}} \mathrm{cm}^{-2}$ were fabricated with $\mathrm{Pt} / \mathrm{C}, \mathrm{Pt}_{3} \mathrm{Ni} / \mathrm{C}$ and $\mathrm{Pt}_{3} \mathrm{Co} / \mathrm{C}(40 \mathrm{wt} \%$ metal loading, FC store) via the following method: catalyst ink was prepared using the catalyst powder, $0.2 \mathrm{~mL} \mathrm{DI} \mathrm{H}_{2} \mathrm{O}$ and $0.8 \mathrm{~mL}$ IPA (Sigma-Aldrich) and sufficient $10 \mathrm{wt} \%$ Nafion ${ }^{\circledR}$ solution (Ion Power Inc., New Castle, USA) to give a Nafion ${ }^{\circledR}: \mathrm{C}$ weight ratio of $0.4: 1$, respectively. A Sonics Vibra-CellTM VCX130 sonication horn $(130 \mathrm{~W})$ was then used at $30 \%$ power for $15 \mathrm{~min}$ in a $10 \mathrm{~s}$ on/10 s off pulse sequence. A $3 \times 5 \mathrm{~cm}^{2}$ rectangular piece of Sigracet 39 BC GDL was then painted with all of the ink and dried on a hot plate at $50{ }^{\circ} \mathrm{C}$. The GDEs were then inserted into the ex situ cell and the aforementioned break in procedure was employed followed by two CVs in the range $0.05-1.2 \mathrm{~V}$ vs. RHE $\left(20 \mathrm{mV} \mathrm{s}^{-1}\right)$. The gas was then switched to $\mathrm{O}_{2}$ and the OCP was measured and recorded after obtaining a stable value for at least $200 \mathrm{~s}$. Potentio-electrochemical impedance spectroscopy (EIS) was then employed at $0.9 \mathrm{~V}$ vs. RHE in the frequency range of $10 \mathrm{kHz}-0.1 \mathrm{~Hz}$. Finally, linear sweep voltammetry (LSV) was obtained from $1.2-0.05 \mathrm{~V} \mathrm{vs}$. RHE at $10 \mathrm{mV} \mathrm{s}^{-1}$. The catalyst loading experiments were carried out at $30^{\circ} \mathrm{C}$. 


\section{2. $\mathrm{O}_{2}$ Solubility Measurements}

$\mathrm{O}_{2}$ solubility in the electrolyte was measured using a WPI ISO2 oxygen sensor (World Precision Instruments, Sarasota, USA). Calibration was conducted using the nA scale in $\mathrm{N}_{2}$, air and $\mathrm{O}_{2}$ saturated $\mathrm{H}_{2} \mathrm{O} . \mathrm{O}_{2}$ was bubbled into $5 \mathrm{~mL}$ of each acid solution for at least $5 \mathrm{~min}$ and the sensor was used immediately after removal of the bubbler. The probe was left to soak in $\mathrm{H}_{2} \mathrm{O}$ between measurements.

\subsection{MEA Fabrication and In-Situ Testing}

MEAs with an active area of $2 \times 2 \mathrm{~cm}^{2}$ were fabricated using Nafion ${ }^{\circledR} 212$ membrane (Fuel Cell Store, Texas, USA) and GDEs with varied catalyst loading. The GDEs and the membrane were hot pressed at $140{ }^{\circ} \mathrm{C}$ under 1 tonne of pressure for 2 min to make the MEA. The catalyst layer was applied on the Sigracet 39BC GDL using the method described in the catalyst loading Section 2.1. To understand the effect of the catalyst layer on the in situ OCP results, the catalyst loading and the Nafion ${ }^{\circledR}$ loading for the GDEs were varied. MEAs of the following catalyst loadings $\left(\mathrm{mg}_{\mathrm{Pt}} \mathrm{cm}^{-2}\right)$ were fabricated: anode: cathode; 0.4:0.2, 0.2:0.2, 0.1:0.2, 0.05:0.2, 0.4:0.4, 0.2:0.2, 0.1:0.1, 0.05:0.05.

The MEAs were tested using a fuel cell test system (Scribner 850e, North Carolina, USA) at $80{ }^{\circ} \mathrm{C}$ with back pressure $1.5 \mathrm{bar} / 1.3 \mathrm{bar}$, flow rate $150 \mathrm{~mL} \mathrm{~min}{ }^{-1} / 300 \mathrm{~mL} \mathrm{~min}{ }^{-1}$ and stoichiometry 1.3/1.5 at the anode/cathode, respectively. The MEA was conditioned with air at the cathode at $0.6 \mathrm{~V}$ at $100 \% \mathrm{RH}$ for $6 \mathrm{hrs}$ before purging the cathode with $\mathrm{N}_{2}$ gas. $100 \mathrm{CV}$ s were run in the range $0.05-1.2 \mathrm{~V}$ vs. RHE at $100 \mathrm{mV} \mathrm{s}^{-1}$ followed by 2 in the same potential range at $20 \mathrm{mV} \mathrm{s}^{-1}$. The cathode gas was then switched to $\mathrm{O}_{2}$ and the humidifier was cooled to achieve $25 \% \mathrm{RH}$ on both sides. The potential was held at $0.6 \mathrm{~V}$ for $1 \mathrm{hr}$ before conducting the measurements. OCP, a polarisation curve using a current hold method and an EIS at $0.9 \mathrm{~V}$ DC was obtained. The humidity was then increased by $25 \%$ and the procedure repeated. For MEAs with Pt loading of 0.4:0.2, 0.1:0.2 and 0.05:0.2 $\mathrm{mg}_{\mathrm{Pt}} \mathrm{cm}^{-2}$, the MEA was switched around and the entire procedure repeated.

\section{Conclusions}

Initial examination of the Nernst equation showed the synergistic effects of cell temperature, inlet pressure and $\mathrm{RH}$ on the theoretical maximum potential that can be achieved in a PEMFC system. Using ex situ GDE tests, the temperature dependency was examined further, where an approximate $>150 \mathrm{mV}$ disparity between the measured OCP and theoretical OCP was found as a result of oxidative currents such as the mixed potential, all in the absence of $\mathrm{H}_{2}$ crossover. An alternative aqueous model for the Nernst potential was then derived showing the same relationship with the gaseous model to cell temperature but illustrating a more realistic conceptualisation to the Nernst equation, which would become more valid if the system was considered to not be at steady state.

The measured OCP ex situ was found to decrease linearly with an increased electrolyte concentration and is thought to primarily coincide with a measured $\left[\mathrm{O}_{2}\right]$ gradient of $-0.364 \mathrm{mM} \mathrm{M}_{\text {acid }}{ }^{-1}$ indicating a clear relation of $\mathrm{O}_{2}$ solubility to measured OCP. This conclusion was later supported by MEA tests where an increase in $\mathrm{H}_{2}$-crossover at lower $\mathrm{RH}$ could not fully account for a drop in measured OCP and so it is thought that a combination of reduced local $\mathrm{O}_{2}$ solubility/permeability and ORR inhibition are probable causes. Deconvoluting the relationship between ionomer structure, $\mathrm{O}_{2}$ permeability and kinetic activity on the OCP of operational PEMFCs would therefore be of great interest. The effect of electrolyte concentration here provides an indication as to what might be expected for ionomers with lower equivalent weight (i.e., low equivalent weight corresponding to a higher concentration of sulfonic acid groups).

Nevertheless, the dependency of OCP on the catalyst surface area and ORR activity was also shown with the explanation that at steady state, oxidative currents induce a compensating ORR reaction from the catalyst. The higher the exchange current density, the lower the overpotential associated with this process; thus, higher OCPs were found for $\mathrm{Pt}_{3} \mathrm{Ni} / \mathrm{C}$ and $\mathrm{Pt}_{3} \mathrm{Co} / \mathrm{C}$ catalysts in comparison to $\mathrm{Pt} / \mathrm{C}$. In addition, the higher the catalyst 
surface area, the lower the oxidative current density normalised to said area and thus the overpotential is also lower. This effect was also found in single cell tests, albeit with higher overpotential as a result of $\mathrm{H}_{2}$ crossover. It is the hope that these results better illustrate the dependencies of the measured OCP and thus help the community to better conceptualise measured polarisation performance curves.

Supplementary Materials: The following are available online at https:/ / www.mdpi.com/article/ 10.3390/catal11080965/s1. Table S1: Standard enthalpies and entropies for PEMFC. Figure S1: Calculated [O2] and [H2] in the temperature range $30-80{ }^{\circ} \mathrm{C}$. Figure S2: The LSVs for a Pt/C GDE ex-situ before and after corrections. Figure S3: The Tafel region for all of the Pt/C ex-situ GDE samples. Figure S4: The Tafel slope measured for all ex-situ GDE samples vs. Pt surface area. Figure S5: The exchange current density normalised to Pt surface area vs. Pt surface area. Figure S6: An example polarisation performance curve before and after $\mathrm{H} 2$ crossover and internal resistance corrections. Figure S7: Measured H2 crossover current vs. Pt surface area at the anode. Figure S8: A comparison of the measured and calculated (by Tafel analysis) crossover currents for the MEAs at all relative humidity's.

Author Contributions: Conceptualization, A.E.-k. and P.M.; methodology, P.M.; formal analysis, P.M.; investigation, P.M. and A.E.-k.; resources, A.E.-k.; data curation, P.M.; writing-original draft preparation, P.M.; writing-review and editing, A.E.-k., I.C. and T.S.; visualization, P.M.; supervision, A.E.-k.; project administration, A.E.-k.; funding acquisition, I.C. and T.S. All authors have read and agreed to the published version of the manuscript.

Funding: This research received no external funding.

Acknowledgments: The authors would like to acknowledge Toyota Motors Europe for funding this activity under the Young Investigator Fellowship 2018.

Conflicts of Interest: The authors declare no conflict of interest.

\section{Nomenclature}

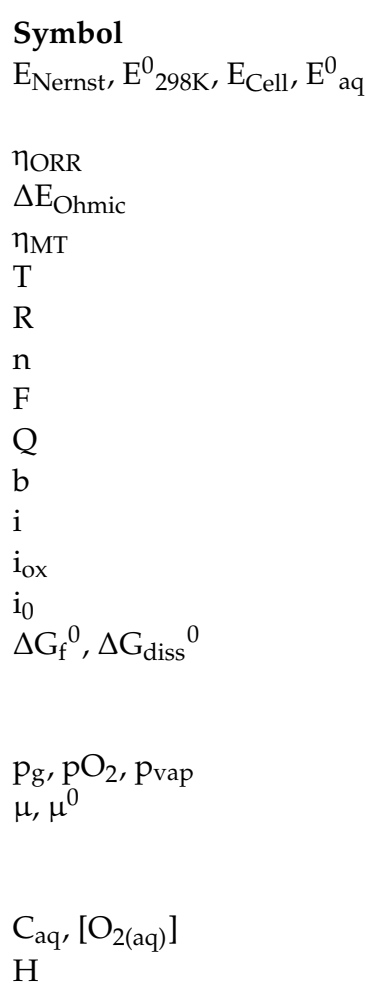

\section{Meaning}

Nernst potential, Standard potential at 298 K, Cell potential, Standard potential of the aqueous model. Overpotential from the ORR

Ohmic loss of potential

Overpotential of mass transport

Temperature

Gas constant

Number of electrons

Faradays constant

Reaction quotient

Tafel slope

Measured current (Abs)

Oxidative currents (Abs)

Exchange current (Abs)

Standard Gibbs free energy change of formation, dissolution. Gaseous or aqueous system denoted by subscripts ' $\mathrm{g}$ ' or 'aq' respectively.

Partial pressure of the gas or vapour, e.g., $\mathrm{O}_{2}$

Chemical and standard chemical potential.

Gaseous or aqueous system denoted by

subscripts ' $\mathrm{g}$ ' or 'aq' respectively.

Concentration of dissolved gas, e.g., $\mathrm{O}_{2}$

Henry's law constant

Units
$\mathrm{V}$
$\mathrm{V}$
$\mathrm{V}$
$\mathrm{V}$
$\mathrm{K}$
$\mathrm{J} \mathrm{mol}$
$\mathrm{N} / \mathrm{A}^{-1} \mathrm{~K}^{-1}$
$\mathrm{C} \mathrm{mol}$
$\mathrm{N} / \mathrm{A}$
$\mathrm{V} \mathrm{dec}$
$\mathrm{A}$
$\mathrm{A}$
$\mathrm{A}$
$\mathrm{J} \mathrm{mol}^{-1}$

$\mathrm{Pa}$

$\mathrm{J} \mathrm{mol}^{-1}$

$\mathrm{M}$

$\mathrm{MPa}^{-1}$ 


\section{References}

1. Wang, Y.-J.; Long, W.; Wang, L.; Yuan, R.; Ignaszak, A.; Fang, B.; Wilkinson, D.P. Unlocking the Door to Highly Active ORR Catalysts for PEMFC Applications: Polyhedron-Engineered Pt-Based Nanocrystals. Energy Environ. Sci. 2017, 11, $258-275$. [CrossRef]

2. Stephens, I.E.L.; Rossmeisl, J.; Chorkendorff, I. Toward Sustainable Fuel Cells. Science 2016, 354, 1378-1380. [CrossRef]

3. Kongkanand, A.; Mathias, M.F. The Priority and Challenge of High-Power Performance of Low-Platinum Proton-Exchange Membrane Fuel Cells. J. Phys. Chem. Lett. 2016, 7, 1127-1137. [CrossRef]

4. $\quad$ El-kharouf, A.; Mason, T.J.; El-kharouf, A.; Mason, T.J.; Brett, D.J.L.; Pollet, B.G. Ex-Situ Characterisation of Gas Diffusion Layers for Proton Exchange Membrane Fuel Cells Ex-Situ Characterisation of Gas Diffusion Layers for Proton Exchange Membrane Fuel Cells. J. Power Sources 2012, 218, 393-404. [CrossRef]

5. El-kharouf, A.; Steinberger-Wilckens, R.; Rees, N. Gas Diffusion Layer Materials and Their Effect on Polymer Electrolyte Fuel Cell Performance-Ex Situ and In Situ. Fuel Cells 2014, 14, 735-741. [CrossRef]

6. Hamilton, P.J.; Pollet, B.G. Polymer Electrolyte Membrane Fuel Cell (PEMFC) Flow Field Plate: Design, Materials and Characterisation. Fuel Cells 2010, 10, 489-509. [CrossRef]

7. Huang, J.; Li, Z.; Zhang, J. Review of Characterization and Modeling of Polymer Electro- Lyte Fuel Cell Catalyst Layer: The Blessing and Curse of Ionomer. Front. Energy 2017, 11, 334-364. [CrossRef]

8. Dicks, A.; Larminie, J. Fuel Cell Systems Explained; Wiley: Hoboken, NJ, USA, 2003.

9. Siroma, Z.; Kakitsubo, R.; Fujiwara, N.; Ioroi, T.; Yamazaki, S.; Yasuda, K. Depression of Proton Conductivity in Recast Nafion ${ }^{\circledR}$ Film Measured on Flat Substrate. J. Power Sources 2009, 189, 994-998. [CrossRef]

10. Kocha, S.S.; Yang, J.D.; Yi, J.S. Characterization of Gas Crossover and Its Implications in PEM Fuel Cells. Am. Inst. Chem. Eng. 2006, 52, 1916-1925. [CrossRef]

11. Baik, K.D.; Hong, B.K.; Kim, M.S. Effects of Operating Parameters on Hydrogen Crossover Rate through Nafion Membranes in Polymer Electrolyte Membrane Fuel Cells. Renew. Energy 2013, 57, 234-239. [CrossRef]

12. Nie, Y.; Li, L.; Wei, Z. Recent Advancements in Pt and Pt-Free Catalysts for Oxygen Reduction Reaction. Chem. Soc. Rev. 2015, 44, 2168-2201. [CrossRef] [PubMed]

13. Li, M.; Li, M.; Zhao, Z.; Cheng, T.; Fortunelli, A.; Chen, C.; Yu, R.; Gu, L.; Merinov, B.; Lin, Z.; et al. Ultrafine Jagged Platinum Nanowires Enable Ultrahigh Mass Activity for the Oxygen Reduction Reaction. Science 2016, 9050, 1414-1419. [CrossRef]

14. Debe, M.K. Electrocatalyst Approaches and Challenges for Automotive Fuel Cells. Nature 2012, 486, 43-51. [CrossRef]

15. Zhang, J.; Tang, Y.; Song, C.; Zhang, J.; Wang, H. Short Communication PEM Fuel Cell Open Circuit Voltage (OCV) in the Temperature Range of $23^{\circ} \mathrm{C}$ to $120^{\circ} \mathrm{C}$. J. Power Sources 2006, 163, 532-537. [CrossRef]

16. Vilekar, S.A.; Datta, R. The Effect of Hydrogen Crossover on Open-Circuit Voltage in Polymer Electrolyte Membrane Fuel Cells. J. Power Sources 2010, 195, 2241-2247. [CrossRef]

17. Bockris, J.O.M.; Srinivasan, S. Fuel Cells: Their Electrochemistry; McGraw-Hill: New York, NY, USA, 1969.

18. Barbir, F. PEM Fuel Cells-Theory and Practice; Elsevier: Amsterdam, The Netherlands, 2013.

19. Reimer, U.; Cai, Y.; Li, R.; Froning, D.; Lehnert, W. Time Dependence of the Open Circuit Potential of Platinum Disk Electrodes in Half Cell Experiments. J. Electrochem. Soc. 2019, 166, F3098-F3104. [CrossRef]

20. Sander, R. Compilation of Henry's Law Constants (Version 4.0) for Water as Solvent. Atmos. Chem. Phys. 2015, 15, 4399-4981. [CrossRef]

21. Garsany, Y.; Baturina, O.A.; Swider-Lyons, K.E.; Kocha, S.S. Experimental Methods for Quantifying the Activity of Platinum Electrocatalysts for the Oxygen Reduction Reaction. Anal. Chem. 2010, 82, 6321-6328. [CrossRef]

22. Gasteiger, H.A.; Panels, J.E.; Yan, S.G. Dependence of PEM Fuel Cell Performance on Catalyst Loading. J. Power Sources 2004, 127, 162-171. [CrossRef]

23. Shinagawa, T.; Garcia-esparza, A.T.; Takanabe, K. Insight on Tafel Slopes from a Microkinetic Analysis of Aqueous Electrocatalysis for Energy Conversion. Nat. Publ. Gr. 2015, 5, 13801. [CrossRef] [PubMed]

24. Eberle, D.; Horstmann, B. Oxygen Reduction on Pt(111) in Aqueous Electrolyte: Elementary Kinetic Modeling. Electrochim. Acta 2014, 137, 714-720. [CrossRef]

25. Mukerjee, S.; Srinivasan, S.; Soriaga, M.P.; Mcbreen, J. Role of Structural and Electronic Properties of Pt and Pt Alloys on Electrocatalysis of Oxygen Reduction. J. Electrochem. Soc. 1995, 142, 1409-1421. [CrossRef]

26. Gasteiger, H.A.; Kocha, S.S.; Sompalli, B.; Wagner, F.T. Activity Benchmarks and Requirements for Pt, Pt-Alloy, and Non-Pt Oxygen Reduction Catalysts for PEMFCs. Appl. Catal. B Environ. 2005, 56, 9-35. [CrossRef]

27. Schalenbach, M.; Hoefner, T.; Paciok, P.; Carmo, M.; Lueke, W. Gas Permeation through Nafion. Part 1: Measurements. J. Phys. Chem. C 2015, 119, 25145-25155. [CrossRef]

28. Zhang, H.; Li, J.; Tang, H.; Lin, Y.; Pan, M. Hydrogen Crossover through Perfluorosulfonic Acid Membranes with Variable Side Chains and Its Influence in Fuel Cell Lifetime. Int. J. Hydrog. Energy 2014, 39, 15989-15995. [CrossRef]

29. Kudo, K.; Suzuki, T.; Morimoto, Y. Analysis of Oxygen Dissolution Rate from Gas Phas into Nafion Surface and Development of an Agglomerate Model. ECS Trans. 2010, 33, 1495-1502. [CrossRef]

30. Kudo, K.; Morimoto, Y. Analysis of Oxygen Transport Resistance of Nafion Thin Film on Pt Electrode. ECS Trans. 2012, 50, 1487-1494. [CrossRef] 
31. Suzuki, T.; Kudo, K.; Morimoto, Y. Model for Investigation of Oxygen Transport Limitation in a Polymer Electrolyte Fuel Cell. J. Power Sources 2013, 222, 379-389. [CrossRef]

32. Jinnouchi, R.; Kudo, K.; Kitano, N.; Morimoto, Y. Molecular Dynamics Simulations on $\mathrm{O}_{2}$ Permeation through Nafion Ionomer on Platinum Surface. Electrochim. Acta 2016, 188, 767-776. [CrossRef]

33. Snyder, J.; Fujita, T.; Chen, M.W.; Erlebacher, J. Oxygen Reduction in Nanoporous Metal-Ionic Liquid Composite Electrocatalysts. Nat. Mater. 2010, 9, 904-907. [CrossRef] [PubMed]

34. Mardle, P.; Thirunavukkarasu, G.; Guan, S.; Chiu, Y.-L.; Du, S. Comparative Study of PtNi Nanowire Array Electrodes toward Oxygen Reduction Reaction by Half-Cell Measurement and PEMFC Test. ACS Appl. Mater. Interfaces 2020, 12, 42832-42841. [CrossRef] [PubMed] 